\title{
ISLAM IN WESTERN SOUDAN
}

THERE is at the present moment probably no question of deeper practical interest to the European Powers, who for political and commercial objects have partitioned Africa among themselves, than the question of Islam in Soudan, both Eastern and Western. The elaborate Report of Sir Frederick Lugard, High Commissioner of Northern Nigeria, presented to Parliament in February, 1902, is almost of pathetic interest, considering the vastness of the area and the multitudinous Muslim population under his rule, and having regard also to the slender outfit at his command for administrative work. Public attention, in a most unusual degree, has been attracted to that important region, recently brought within the British Empire.

Civilisation, within the last fifty years, has advanced with rapid strides, and the solidarity of humanity is being more and more recognised. Religion and race are ceasing to be barriers between man and man. "The steamship and the railway, and the thoughts that shake mankind," are annihilating distances and reducing differences and distinctions between communities alien to each other and living in various climes and countries.

The AFrican Society is an offspring and illustration of the spirit of the times. So far as Africa is concerned, Miss Kingsley, whose memory it commemorates, has created a new standpoint for European thought. She has made it possible for African conditions, whether intellectual, social or religious, to be studied by outsiders with patience and without prejudice; and the impulse she has given in that righteous direction will never be spent, because if the human intellect in its investigations can only be made to hold the scale with steady hand, whatever the interests involved, it will arrive at knowledge which will act at once as guide and stimulus to further research; and the more 
men can be made to look at new and fresh landscapes in the intellectual as in the physical world, the more they see, and the more they see the more they desire to see.

It is with these views that I venture to invite the readers of this Journal to a consideration of the question of ISLAM IN Western Soudan. It is not possible to fix the exact date when that irrepressible faith first entered this portion of Africa; and for the purposes of this discussion a knowledge of that chronological fact is not indispensable. It is sufficient to know that it has behind it in those vast regions a history of centuries. It is an agency which, operating for at least a thousand years in this land, has been the most effective instrument in moulding the intellectual, social, and political character of the millions whom it has brought under its influence; and yet in its particular work in Soudan-the special phases it presents-it has rarely been studied by the foreigner with anything like insight or thoroughness.

The generality of European writers on the subject take it for granted that there is no need for giving special attention to Islam in Africa, for it must only be an imitation if not caricature of Islam in Arabia, just as they allege that Christianity among negroes must always be of a degenerate quality.

At the "Parliament of Religions," held in Chicago in 1893, there were no representatives of Negraic Mohammedanism to tell the story of their faith. Two years ago, an Ecumenical Missionary Conference was held in New York, at which there were delegates from every part of the mission field, and all the contemporary religions of the world were discussed in their effects upon their votaries. But no information was given as to Islam in Soudan. No fewer than one dozen speakers, Missionaries and Secretaries of Missionary Societies, dealt with the general question, but no one attempted to describe Islam as it exists in Negroland. A great deal was said of Africa and a great deal about Mohammedanism, but of Mohammedans in Soudan almost nothing, because no one in that vast gathering knew anything about it at first hand, and very few at second hand.

As at present advised, I know of only two books in the English language which, written by foreigners, have attempted to deal with Islam in Soudan. They are Arnold's Preaching of 
Islam, ${ }^{1}$ and Atterbury's Islam in Africa, ${ }^{2}$ and both these writers confess to having written at second hand. Mr. Arnold is professor of philosophy in the Anglo-Mohammedan College at Aligarh in India. Dr. Atterbury is pastor of the Park Presbyterian Church in New York. In his preface Professor Arnold says: "I can neither claim to be an authority nor a specialist on any of the periods of the history dealt with in this book." Dr. Atterbury, in opening his preface, says: "Perhaps the writer was the better prepared to undertake this investigation from some personal observation of Mohammedanism in India, Egypt and the Turkish Empire."

I cannot but sympathise with these courageous writers in the difficulties which confronted them at the outset of their inquiries. They had never themselves been in Africa, and it is presumable had never conversed with any intelligent Negro Muslim on the subject of his faith. Prof. Amold allows his readers to see both sides of the question. He presents the arguments for and against Islam in Africa without drawing himself any damaging conclusions. Dr. Atterbury produces an array of statements which he takes to be facts, and from these arrives at the conclusion that Islam in Africa makes, on the whole, for evil and not good. He assumes that "Islam in central Africa is little more than a slightly modified fetichism." 8 And he has had followers in this view among his countrymen. Mr. Frederic Perry Noble of Chicago adopts this opinion in his voluminous work on The Redemption of Africa, and reproduces the statement made thirty years ago in the Church Missioniary Intelligencer "that all Musulman Negroes who have read the Quran can be accommodated in the waiting room of Euston station," and "that the priests themselves cannot distinguish between 'mumpsimus' and 'sumpsimus' when they jabber, and do not attempt to understand other Arabic books." 8 Mr. Noble did an enormous and creditable amount of work in journeys to and fro, in advertisements, in correspondence and other literary effort to qualify himself to become an authority on "The Redemption of Africa." He did everything but travel in Africa.

1 Constable, London. $\quad$ Putnam's Sons, New York and London.

- Islam in Africa, p. 149. - Fleming H. Revell Company, Chicaga

- The Redemption of Africa, vol. i. p. 73. 
His whole book is, therefore, a striking illustration of the sentiment from Emerson prefixed to his "Author's Note." "Our books are false by being fragmentary." I may say, in passing, my own experience, and I may venture to add, the experience of numerous competent travellers in Soudanincluding Barth, Thomson, Binger, Dubois, Chevallier-English, German, French, does not confirm the general description of Islam given by Atterbury and Noble. There is, however, on the part of Dr. Atterbury evident earnestness and sincerity; while he never hesitates to call what he thinks a spade a spade, he seems always disposed to acknowledge the merits of what he believes to be genuine metal. He never calls Mohammed an impostor or a false prophet. On the contrary, in his opening chapter he says of "the Great Arabian"-_" He was a true prophet; rather he was a prophet of some truth." In this he differs from the eminent student and scholar who introduces the book. Dr. Ellinwood, to whom one must always listen with respect, speaks of the "pettifogging character" of the Koran. The doctor for the moment probably lost sight of the fact that it was not the Koran he had read, but a translation of the Koran, two very different things. ${ }^{1}$ I am glad that Dr. Atterbury, who represents the younger school of theological thought, is an American of high social and literary standing, because there are millions of people in his country who have a practical interest in this great question; and he is himself a descendant of philanthropists who did a great deal to establish and foster the Republic of Liberia, and to give to the Negro an opportunity in his own fatherland of untrammelled development.

The books of the greatest value on Islam in Africa and most easily accessible are in the French language. The works of Idrisu, Ibn Batuta, Leo Africanus, written in Arabic from 300 to 1000 years ago, have been translated into French and are still standard authorities on the subject. The Tarik e Soudan, an Arabic work of Soudanic authorship, which has recently come

\footnotetext{
1 "It is, in truth, one of the most illusory of conceits to fancy that, by verbal transference, a correct counterpart is obtained of the idea and spirit of a passage. A translation may be etymologically perfect, and yet no more give the force of the original, than the awkward dancing of a bear represents the graceful pirouettes of the ballet."-The Mohammedan Controversy, by Sir William Muir, P., 194
} 
into the field, perhaps the most exhaustive on the history of Islam in Negroland, because the work of the natives themselves is not generally known to English-speaking people, and was, until recently, inaccessible through any European language. It is due to the learning, zeal and energy of the distinguished French Orientalist, M. Houdas, that European scholars can now become acquainted with one of the most important works ever produced in Negroland. The eminent Professor, with prodigious labour and complete success, triumphed over almost insuperable difficulties to give us this valuable work in an admirable French translation. "The Tarik e Soudan," says M. Dubois," "is conceived upon a perfectly clear and logical plan, according to the most correct rules of literary composition .... . It forms, with the exception of the holy writings, the favourite volume of the negro, and is known to the furthest extremity of Western Africa, from the shores of the Niger to the borders of Lake Chad. Barth discovered fragments of it at Gando, and I heard it spoken of in Senegal."

On the General question of Islam, three works since the publication of Muir's Life of Mohamet in 1858 have influenced the judgment of the present generation of European students of the subject, and have furnished them with a new, more accurate, and more fruitful point of view than had ever before prevailed in Europe. These works are: the remarkable articles on "Mahomet" and "The Great Arabian" by Mr. Meredith Townsend in the old National Review ; the article on "Islam," first published in the Quarterly Review and afterwards in the Literary Remains of Emanuel Deutsch; and Mohammed and Mohammedanism by Bosworth Smith. All writers on the subject during the last thirty years-the most belated criticswhether conscious or not-have been more or less under the restraining or stimulating guidance of these works.

I will now say a few words on the faith itself as understood by its intelligent Negro adherents, and then on the practical consequences of their belief upon character and conduct. I have been in close contact with the system and its teachers during the last thirty years, both officially as diplomat representing the British Government, making treaties with Islamic chiefs or as

1 Timbuctoo the Mystcrious, pp. 312-315. 
Educator establishing schools among them. I have discussed religious questions for hours with their Ulemas, Foulahs, Mandingoes, Yorubas. I have studied African compositions both in prose and poetry, bearing upon the Deen, as they love to call Islam.

The Kalimah. According to the best informed representatives of the faith in Negroland, the seven words of the Kalimah, or fundamental creed of the religion, are much misunderstood by Christian writers on the subject. The words of the original are

$$
\text { La ilaha ill Allahu. Mohammad rasul Allak. }
$$

Mr. Gibbon, whom probably the majority of Christian students follow, describes Islam as follows :

"The faith which, under the name of Islam, Mohammed preached to his family and nation, is compounded of an eternal truth and a necessary fiction: That there is only one God, and that Mohammed is the Apostle of God." 1

Gibbon was entirely mistaken in regarding the faith as "compounded." It is this that has misled all who follow his guidance. Even writers acquainted with Arabic have surrendered their judgment to the witchery of his grandiose periods. As far as we can gather he was not acquainted with Arabic. His estimate of Islam was to a great extent the result of the imaginings of early youth. "Before I was sixteen," he tells us in his autobiography, "I had exhausted all that could be learned in English of the Arabs and the Persians, the Tartars and Turks; and the same ardour urged me to guess at the French of d'Herbelot and to construe the barbarous Latin of Pocock's Abulfaragius." Macaulay speaks of "that unpleasant trick, which Gibbon brought into fashion, the trick, we mean, of telling a story by implication and allusion" 2 And yet he has wielded for more than a century an irresistible spell over ardent and generous youth. Mr. Perry Noble says in a note, "Imperial Gibbon's grand style may have unconsciously influenced the author of these volumes. If so, he would be fain to acknowledge his indebtedness in the words of Dante to Vergil: Thou art my 
master and the author of my style. . But students do not nowadays go to Gibbon either for "style" or opinions about religion, It is difficult to understand what he could teach bearing upon the "Redemption of Africa."

Dr. Atterbury gives what he believes to be the doctrine of Islam "from the highest authority in the world," the Sheik-ulIslam. In giving the Kalimah the translator misrepresents the words of the original, adopting the usual phrase, "there is only one God, and Mohammed is His prophet." We can sympathise with Dr. Atterbury when Dr. H. U. Wertbrecht, a Church Missionary in India, and long resident in Mohammedan lands, makes the astounding statement that in Islam "God and the prophet are coupled together as objects of faith." 3 The most elementary knowledge of Islam should have prevented so gross an error. According to African Muslims the idea is in the last degree blasphemous. But Mr. Townsend in his article on "Mohamet" "expressed a somewhat similar view, pardonable half a century ago, but inexcusable now in a writer of $\mathrm{Dr}$. Weitbrecht's exceptional opportunities for learning the truth. $\mathrm{Mr}$. Townsend said : "The crime of Mohamet consists not in putting forth his commands to do justice and love mercy as the word of the Lord, but in asserting that he could never speak anything except that word." 6 Lord Houghton is more accurate. He says: "The humility of Mohammed in all that concerns his personality is conspicuous throughout the Koran. 'I do not say unto you, that in my possession are the treasures of God, nor that I know what is unseen; nor do I say unto you, Verily I am an angel, $-I$ only follow what is revealed to me.' Sura vi-50. 'Mohammed is nought but an Apostle; other Apostles have passed away before him.' Sura iii-138. Nor does Mohammed even attribute to himself any specialty of nature such as he gives to Christ, whom he declares to have been born of a Virgin by the Spirit of God." *

Professor Arnold also represents the creed as one sentence.?

1 The Redemption of Africa, p. xv. 2Islam in Africa, p. 19.

- Church Missionary Intelligencer, Nov. 1899 . 'National Review, July, 1858.

- I see thal this sentence has not been reproduced in Mr. Totwnsend's able article on "The Great Arabian" in his interesting volume on Asia and Europe.

- Pactical Works, vol. i. p. $182 . \quad$ TPreaching of Islam, p. 336.

2 Vol 2 
He speaks of the "first half" of it and the "second half," and connects them by a copulative conjunction thus: "There is no God but God and Mohammed is the Prophet of God." But an accurate version would be "There is no God but the God," the Being whom or which all nations and races unconsciously worship. I say unconsciously, because none really know Him whose name, as Malachi says, "is great among the nations, and to Whose name in every house incense is offered and a pure offering "1

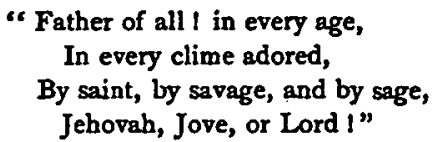

-the Lord, according to the opening chapter of the Koran, of the three worlds, the Merciful, the Compassionate, whose tender mercies are over all $\mathrm{His}$ works, rational and irrational; "Who maketh His sun to rise on the evil and on the good, and sendeth rain on the just and on the unjust."

The distinction between the two words translated God in the Kalmah is not to be indicated by merely writing the second word with a capital $G$. There are no capital letters in Arabic. The distinction is marked by the use before the second word of the definite article, which disappears in the ordinary translation. Mr. Muir ${ }^{2}$ translates ALLAH by the LORD, retaining the article but departing from the radical signification of the word, unless we are to understand by "the Lord" the idea expressed by Yahveh, which would not be far from that intended by Al-ilah or Allah the God, the only Adorable One.

To translate, as is the common practice, "There is no God but God and Mohammed is His Prophet" is to introduce the anthropomorphic idea so strongly and everywhere repudiated in the Koran. The ideas conveyed in the two sentences are, according to African Muslims, unapproachably separate, and they can be connected by no conjunction either copulative or adversative. No pronoun representing the Supreme Being is admitted. There is no $H$ is and the word which describes Mohammed is not Prophet but Apostle-Messenger.

A correct translation of the second sentence of the Kelmiah 
would be, "Mohammed is an Apostle of God," not the Apostle. The noun rasul, Apostle, has no article. Lane, than whom there is probably no higher authority, translates "Mohammed is God's Apostle." 1 Mohammed is related to have said that there were 124,000 Prophets and 313 Apostles or messengers. ${ }^{2}$ The Apostle may include the Prophet but the Prophet never includes the Apostle. Mohammed did not arrogate to himself, as some Christian. controversialists and many Muslim commentators strive to make him do, the position of the only prophet or messenger of God. Nor did he teach, as some theologians among his countrymen try to assert for him, that he was the last of the Prophets in the sense of the limitation of Divine communications to him and those before him. The passage of the Koran on which the latter assumption is based is Sura xxxiii. 40. "Mohammed is not the father of any man among you, but an Apostle of God and a seal of the Prophets." The supporters of the opinion of the finality of Mohammed's revelations interpret seal as implying the closing for ever of the door of revelation, to be opened no more. On the other hand, there are those who interpret the word in the light of numerous other passages in the Koran, where Mohammed is called confirmer, corroborator, Amen sayer, to the teachings of preceding prophets, just as the seal is attached to legal instruments in testimony of the good faith of what has gone before, a theory which does not exclude the idea of Prophets and Apostles after Mohammed. The term musadiqun, corroborator, is also applied to Jesus and other prophets. The phrase "seal of the prophets," applied to Mohammed occurs only once in the Koran; and he is called $a$ seal, not the seal as generally translated. Many Muslim writers in letters and more formal documents, instead of following the complimentary references to the Prophet by the phrase la nabi ba'ad hu, "after whom there is no prophet," use Alkhatimu lima sabuka, the seal of what has gone before.

Mohammed then is, according to the teachings of the Koran, a Messenger, one of the Messengers, of the Supreme and Universal God. The Faith of Islam is neither Henotheism nor Saccrdotalism. It is not the worship of one God, as exclusively the God of the Arabs, adapted to and preferable for Arabia to

\footnotetext{
1 Modern Egyptions, chap. iii. Mischat-ul-Masabih, book xxiv, chap. i.
} 
all others, in the sense in which Cicero said, "Every State has its own god, and we have ours;" or as Elohim was at one time regarded by the Jews. Islam is monotheism, not only as contrasted with polytheism, but also as expressing the idea of universal, unapproachable, incomparable, and solitary supremacy. It is the worship of a Being without name or place or sex, not to be defined by human speech-the altogether Unknown. The Naza miyah sect of Muslims ${ }^{1}$ believe that it is lawful to speak of the Almighty as a thing, shai.' Paul spoke of "that which (the thing which) ye ignorantly worship." "The Power that makes for righteousness" is A nnold's well-known phrase, not who makes, etc. The anthropomorphic tendency would change the which in the Lord's Prayer to who to agree with its antecedent Father-a male Being. This would probably be correct grammar, but, I venture to think, not sound science or philosophy. Science begins and ends with agnosticism. The process is, Non scivi, non scio, non sciam. I did not know, I do not know, I shall not know. To call a man distinguished for his knowledge a scientist or scientific man is from his standpoint a description of the lucus a non lucendo kind. "I suppose," said Darwin, "I must write myself down as an Agnostic." The Divine revelations, according to Islam, have no prescriptive or exclusive channels; no class are special intermediaries for the conveyance of Divine truth to mankind. No place is the chosen spot for the Divine teachings or worship.

The essence of the creed is not to be judged by the utterances of its ordinary votaries. There is a native dogmatism in human nature caused by fancying for one's self or one's teachers a private monopoly of God. Hence there are Mohammedans, as there are Christians and Jews and Buddhists, who, inferior to the true teachings of their creed, cannot believe that God is where $\mathrm{He}$ is not reached by such paths as those they have been taught are the only paths that lead to Him.

All earnest students of Islam must recognize the justice of the following indignant and energetic criticism recorded by $\mathrm{Mr}$. Townsend in 1858 and reproduced in 1901 :-

"The living law of Mohammedanism is not to be found in the Koran, but in the commentators-a set of the most vicious

1 Iughes's Distionary of Islam, p. 568. 
scoundrels who ever disgraced humanity, whose first object seems to have been to relax the plain meaning of the original edicts as far as practicable." 1

Mr. Stanley Lane Poole, a higher authority, at least a later witness than Mr. Townsend, says :

"A large part of what Muslims now believe and practise is not to be found in the Koran at all ..... For ourselves we prefer the Koran to the religion as it is now practised, and we are glad to think that we do not owe all the results of modern Islam to the sacred book on which it is supposed to rest. There is a peculiar simplicity about the Koran. . . . . . . . . . . . . It is the broken utterance of a human heart wholly incapable of disguise; and the heart was that of a man who has influenced the world as only One other has ever moved it." 2

Whenever I refer educated African Muslims to frequent discrepancies between the teachings and examples of the Arabs and the plain doctrines of the Koran, they invariably reply in the language of the Koran itself (Sura ix-98):

$$
\text { Al-Aräb ashad kufran wa ntfákan. }
$$

"The Arabs are most stout in unbelief and hypocrisy, and are more likely not to know the bounds which God has sent down to His Apostle."

This passage has protected the Soudanic Muslims against undue reverence for the Arab and armed him against imposition from the wiles of the unscrupulous among the countrymen of the Prophet.

Mr. Lane Poole indirectly furnishes another proof of the sincerity of the Prophet of Islam in the remark that "Mohammed in part destroyed the Arab when he created the Muslim." 8

So again, when African Muslims are approached on the subject of surrendering their religion for that of Europe, they refer to the various sects and divisions of the "People of the Book," in which phrase they include Christians and Jews, quoting again the words of the Koran (Sura ii. 107) :

"The Jews say, 'The Christians rest on nothing'; and the Christians say, 'The Jews rest on nothing.'"

\footnotetext{
1 Asia and Europe, p. $211 . \quad$ Studies in a Mosque, pp. 167, 168.

Studies in a Mosque, p. 33.
} 
They are thus protected against undue ascendency among them of either Arab or European peculiarities.

Having endeavoured to define the two fundamental articles of the Muslim creed as expounded by its African professors, let us now see how far Mohammed's teachings agree with the belief of Christendom as expressed in the Apostles' Creed. I have frequently discussed this Creed with African Muslims. Take the clauses separately;

"I believe in God the Father Almighty, Maker of heaven and earth."

Excepting the word "Father" Mohammedans accept this.

"And in Jesus Christ His only Son our Lord."

This they believe, excepting the words His only Son.

"Who was conceived by the Holy Ghost, Born of the Virgin Mary, suffered under Pontius Pilate."

This they accept.

"Was crucified, dead and buried. He descended into hell : the third day he rose again from the dead."

This they reject on Koranic authority. Sura iii. 47,48 .

"He ascended into heaven."

This they believe.

They reject what follows down to the word " dead."

All the remainder, beginning with "I believe in the Holy Ghost" they accept ex animo.

With regard to the miraculous Birth of Christ, Mohammedans hold much more decided views than many Christians. The Prophet said :

"Whosoever shall bear witness that there is one God; and that Mohammed is His servant and messenger ; and that Jesus Christ is His servant and messenger; and that he is the son of the handmaid of God, and that he is the Word of God, the word which was sent to Mary, and Spirit from God, will enter into paradise." 1

Rodwell thinks that Mohammed believed in the Immaculate and miraculous conception of Christ. ${ }^{2}$ If Christ is not called the Son of God in the Koran, he is never called, as he is frequently

1 Mishkat-ul-Masabih, i. 11.

2 Transiation of the Koran, p. 155 (note). 
in the New Testament, the "Son of Man." The "Son of Mary" is the only appellation. ${ }^{1}$

On the other hand, the Times (June 13, 1902), reviewing a remarkable volume ${ }^{2}$ recently published, informs us that "criticism not obscurely suggests that all those elements in the Gospels which ascribe to Christ a miraculous Birth and a Divine Nature are the creation of the Church's reflective consciousness and the product of her adoration of Christ." Again : "It is said to be the case that of all the Articles of the Creed this is the most beset with difficulties in the judgment of our educated youth."

The Koran ascribes the Divine choice of Mary to her purity and chastity (Sura xxi. 92). The positive idea of preference as a reward of virtue is emphasized. In the Te Deum it is said, "When Thou tookest upon Thee to deliver man, Thou didst not abhor the Virgin's womb." This is somewhat modified, I think with advantage, in the Prayer Book of the Catholic Episcopal Church of the United States.

We will now consider the practical consequences of his Creed upon the character and conduct of the Soudanese Muslim.

It brings to him a consciousness of his place as a distinct, rational, responsible individuality, allied to the highest intelligences of the universe, all moving in entire subordination and submission to the one Supreme Will; none by virtue of nationality or race taking precedence in the family of the Faithful. Its invocations are always for the Prophet and his followers. The Prophet and all his people are one. Only God is supreme. Man, according to this system, is above all created beings, and inferior, whatever his worldly position, only to the Creator, who when He had made man commanded the angels to prostrate themselves before the new creature (Sura. ii, 32). But man is in no way allied to the Almighty, nor is he in any way connected with the beast of the field. There is neither anthropomorphism nor totemism in Islam. This creed has wrought upon the Africans as individuals or communities im-

1 After this, it is surprising to read the following from so eminent an authority as Sir William Muir : "The Coran itself contains no doctrine peculiar to Christianity, if perhaps we except the Resurrection from the dead, and the Life to come; and even these are travestied and cast into the mould of rabbinical legend." - The Mahommedan Controversy, p. 129.

- Contentio Veritatis. By Six Oxford Tutors. 
provements which the system evolved or rather derived in Europe from Semitic teachings is helpless to produce, hampered as it is by the concomitants of so-called civilisation, which as a social or spiritual force are disintegrating and destructive.

Civilisation has its advantages and disadvantages, its privileges and its burdens; the White Man's Burden and the Black Man's Burden. To the African, forced to come into contact with it, the religion of Islam furnishes the greatest solace and the greatcst defence. To him it is praesidium as well as dulce decus. The foreigner never fails to respect him when he presents himself with the badge of the faith of Mohammed.

The religion of Arabia has this feature-that it has been preached to, accepted by, and become the abiding faith of members of all the known races-Caucasian, Mongolian, Negro. Shem, Ham and Japhet, all unite under its banner and speak its language. Christianity has never been able thus to unite distinct and dissimilar races. Ham and Shem have never found cordial and unqualified welcome in its fold, whether Roman, Anglican, or Puritan. Yet its Japhetic professors have assumed that all races. outside its fold should not only enter, but are anxious to enter. When, however, through special efforts made to secure them strangers come "from many an ancient river, and from many a palmy plain," they are assigned a back seat. They are not allowed to share in the brotherhood and equality promised. "Hitherto shalt thou come and no further" is the practice, if not the law of the religion. And yet Dr. Weitbrecht, with all the facts before him, deliberately says that "the tribes converted to Islam have entered a blind alley which will lead them a certain distance and no farther." 1

Will Dr. Weitbrecht tell us why there are as yet no native Bishops in the Church of England in India? The propriety or necessity for such an appointment was suggested by Rev. J. Thomas, a European missionary in India, to Rev. Henry Venn, Honorary Secretary of the Church Missionary Society, in 1864 The idea was endorsed both by Mr. Venn and Dr. Cotton, Bishop of Calcutta. ${ }^{2}$ This was forty years ago ; and yet nothing in that direction has been attempted. And it would seem that

1 Church Missionary Intelligencer, Nov. 1899.

- Memoir of Rev. Herry Vern, B.D., p. 322. 
Christendom is getting further and further away from the idea of brotherhood. The remarkable article in the Fortnightly Review (August, 1902), on "Negrophilism in South Africa," is heartbreaking to the intelligent African, or would be heartbreaking if he were not reassured by the rapidly spreading influence of Islam over his Fatherland. It is said in the Fortnightly that at all the missionary centres there is "an increasing perception that not literary training, but training to labour is what is required as the first European lesson to the black man." Again many white Christians are troubled by "the importation from the United States of a Negro Bishop of an African Episcopal Church." "The people will endure no equality of black and white in Church or in State."

In West Africa alone, where the white man cannot live, we have in one single locality three native Assistant Bishops, all of the same tribe. One of them, who is recognised by all his people as entirely qualified to be made full Bishop, has the burden laid upon him of raising $£ 10,000$, as an endowment fund, before he can be appointed to a position to which every consideration, except, probably, his colour or race, entitles him. Many of his people are discouraged by this condition imposed upon him and refuse to subscribe.

Christ said, "Go ye into all the world and preach the Gospel," but from the course pursued by his enlightened representatives, it would seem that the command of the Master is impracticable. If a Negro, or an Indian, or a Chinaman, who has embraced Christianity and has been specially trained to preach by qualified Christian teachers, applies to a Missionary Society to be sent to any station outside the dark races, he is told that propriety or circumstances require that he should evangelize his own brethren; and yet it was from a dark race that Europe received the Gospel ; but the moment it crossed the Bosphorus it became racial on the monopoly of Europe. This is not in accordance with the message which Paul, specially sent to evangelize Europe, gave to its people. He told them-what up to this day they seem unable to grasp, even when they profess to be carrying the message the Apostle gave them :-

"As many of you as have been baptized into Christ have put on Christ. 
"There is neither Jew nor Greek, there is neither bond nor free, there is neither male nor female; for ye are all ONE in Christ Jesus." 1

But Great Britain does not hold itself responsible for the popular missionary propaganda. Without, probably, having in mind the particular feature of the case we are pointing out, Lord Salisbury, addressing the Society for the Propagation of the Gospel at the celebration of its two hundredth anniversary, June 19, 1900,? said :-

"This is a great occasion. It is a standpoint in the history not only of our Church, but of our nation."

He then added :-

"I am here perhaps rather as a stranger, for I must not conceal from you that at the Foreign Office missionaries are not popular-(laughter)-and that perhaps the Foreign Office may look upon me as rather a deserter in appearing upon your platform at the present time."

The "occasion" was "a great one," and the Spirit of God, which Renan calls "the soul of the world," gave to the head of the British Government the word in due season. Referring to the Mohammedans his Lordship used the following weighty and carefully prepared language :

"May I say one word more in the same line upon a matter which touches us more closely, and which is seldom absent from our thoughts, and that is the position which this country and those who represent its moral and spiritual forces occupy to those great Mohammedan populations which in so many parts of the world come into close connexion with our rule? I have pointed out to you how difficult it is to persuade other nations that the missionary is not an instrument of the secular Government. It is infinitely more difficult in the case of Mohammedans. He cannot believe that those who are preaching the Gospel against the religion of Mahomet are not incited thereto and protected therein and governed in their action by the secular Government of England with which they are connected . . . And remember that in these Mohammedan countries you are not dealing with men who are wholly evil. You are dealing with men who have a religion, erroneous in many respects, terribly

\footnotetext{
1 Galatians iii. 27, 28.

- At. Exeter Hall.
} 
mutilated in others, but a religion that has portions of our own. embodied in its system. You are dealing with the force which a sincere, though mistaken, theism gives to a vast population. You will not convert them. I do not say that you will never do so-God knows I hope that that is far from our fears. But, dealing with the events of the moment, I think that your chances of the conversion of them as proved by our experience are infinitely small, and the danger of creating great perils and producing serious convulsions, and, it may be, of causing bloodshed which shall be a serious and permanent obstacle to that Christian religion which we desire above all things to preach, is a danger that you must bear in mind."

In accordance with the teachings of such truly Christian statesmanship, the Foreign Office consistently refuses to allow missionaries to operate at Khartoum, its newly acquired responsibility in a Mohammedan country.

Islam, on the other hand, makes room for all. If a Muslim Negro from Soudan or a Malay from India, or a Chinaman from Pekin, is competent he can be sent on any-the most important mission-in connection with his religion, and he will be invited to lead the prayers in any mosque in Europe, Asia, Africa, or America. A Negro Muslim from Sierra Leone has lately been leading the devotions of English Muslims in the mosque at Liverpool. The Sheikh-ul-Islam of England, Abdullah Quilliam, an Englishman, whose nationality does not debar him from holding that high position in the Mohammedan community, delivered by his faith from racial prejudices and restrictions, has named one of his sons after an African slave-BELAL: a name which, Mr. Townsend tells us, though that of a Negro, is in Asia, through his connexion with Islam, better known than that of Alexander the Great. ${ }^{1}$ Sultans and Pashas will take their places in the ranks at the time of prayer behind the black or brown Imam, if only he is qualified to lead or stand before them, as the word means. Mr. Bryce, in his Romanes Lecture, a few months ago, ${ }^{2}$ confessed to the inability of Christianity on this subject as compared with Islam. "Christianity," he said, "with its doctrine of brotherhood, does not create the sentiment of equality which Islam does." This is not the fault of Christianity 
but of the earthen vessel in which the treasure is contained. An Imperial race is incompetent to maintain the simplicity of the Nazarene, and diffuse His teachings as He gave utterance to them. It is not the business of Imperialism to make men but to create subjects, not to save souls, but to rule bodies.

It must have a certain repulsiveness. On its moral side, it must be imperious, with pronounced self-confidence, a certain unsympathising straitness-a pride in itself and an inevitable ignorance of others. It is deficient in spirituality and therefore cannot impart it. Its most successful work for aliens must be on its material side. Well regulated police supervision, technical and industrial schools, hospitals and dispensaries, are its proper and most effective instruments for civilizing and building up backward races.

Islam is the most effective educational force in Negroland. A system of common schools prevails throughout Islamic Africa by which every child is taught to read the Koran in the original and to commit to memory what has been taught. Thousands learn the Koran in this way and thus acquire a familiarity with an immense number of Arabic words, which serve as a bond of union and produce a solidarity of views and of interests which extends from the Atlantic to the Red Sea, and from the Mediterranean to the Equator. And when it is considered that five times a day millions in those latitudes and longitudes repeat in their devotions the same words, it will be seen what a mighty force they form on the continent-Mandingoes, Foulahs, Jalofs, Hausas, Yorubas, and all the vast variety of tribes whose names are not known to Europe, speak each its own vernacular, but when they meet all prostrate themselves before the great Creator with the same words of adoration and self-extinctionAllahu akbar, and grasp each other by the hand with the same language of salutation, in the spirit of the watchword of the Koran.

$$
\begin{aligned}
& \text { اللومعون الهوة } \\
& \text { Almuminuna Ikhwaturn. }
\end{aligned}
$$

"All believers are brethren." How is Christianity, bearing on its back the burden of its caste prejudices, the liquor traffic, and its ethical intolerance, ever to make way among these people? 
African Muslims live only for Islam. The wealthy ones-and there are seldom any paupers among them-use their means for the promotion of intellectual and spiritual education. I was present in 1894 at the dedication of a magnificent mosque erected at Lagos at an expense of $£ 5,000$ by a wealthy native Mohammedan. The Governor of the Colony, Sir Gilbert Carter, presided, and there was present the Sheikh-ul-Islam, Quilliam, appointed by His Majesty the Sultan, Abdul Hamid Khan, to represent him at the ceremony and to invest with a Turkish Order the devoted and patriotic builder.

Six months ago, during a visit which I made to the French colony of Senegal, I saw numerous evidences of the practical interest which the Native Muslims take in Education. One of the largest and most important of the mosques in St. Louis, a two story stone building, 60 by 48 feet, with tiled roof, was erected, I was informed, by private beneficence. Prayers are held in the lower story. The upper story is used for literary gatherings, lectures and discussions. It is surrounded by nine small comfortable dwelling houses, constructed of similar materials, of one story, erected by the same liberal builder of the mosque for the poor, where respectable indigent persons too poor to own or rent houses are given shelter for life. The benefactor, whose name is Ahmad Gouray, I did not have the pleasure of seeing. He had left a few weeks before my arrival on pilgrimage for the second time to Mecca.

The skill of these people in the Arabic language and literature is often marvellous. They not unfrequently surpass in culture their Oriental co-religionists. I have seen Arabs and Moors sit in perfect amazement and as outsiders while listening to the reading and exposition of Arabic books - not excepting the Koran-by Natives of West Africa. M. Felix Dubois says: "The Soudanese doctors were enabled to add the works of their own authors to the books of Bagdad, Cairo, Grenada, which formed the foundations of their libraries. ... A celebrated jurist of Hedjaz (Arabia) arriving in Timbuctoo with the intention of teaching, found the town full of Sudanese scholars. Observing them to be his superiors in knowledge, he withdrew to Fez, where he succeeded in obtaining employment." 1

1 Timbuctoo the Mysterious, Pp. 285 and 302. 
During my visit to Senegal referred to above, through the kindness of His Excellency M. Roume, the Governor-General, to whom I had a letter of introduction from Sir C. A. KingHarman, the Governor of Sierra Leone, and the obliging courtesy of M. Decazes, Director of Native Affairs, I enjoyed exceptional opportunities for studying the situation as it relates to Mohammedans. The chief Government Interpreter, Al Hagg Ahmad Sek, a Jalof, thoroughly educated in French and Arabic, and who has performed the pilgrimage to Mecca, was placed at my disposal. Among other places of interest this gentleman took me to the Mohammedan Court, over which Alkadi (Judge) Bakai $\mathrm{Ba}$, a Native, presides-a man much above the ordinary size, of splendid physique and commanding presence, severe, though dignified of aspect, with a voice of masculine and impressive strength. He sat at his desk surrounded by Arabic law books printed and in manuscript. He conversed with equal ease in French and Arabic, and in Foulah or Mandingo, with the interpreters, Mohammed Sanusi and Momodu Wakka, whom I took with me from Sierre Leone. His decisions, I was told by the Governor-General, in all civil and religious cases affecting his co-religionists, are final.

Islam in Soudan is propagated by self-supporting missionaries without supervision or emolument from any recognised or directing centre. I have often seen these missionaries in remote and sequestered pagan towns and villages, away from the public eye, earnestly teaching and preaching the Unity of God and the Mission of His Apostle, and teaching children and youth. What these men do never appears in any newspaper, foreign or local, to be brought back to them either in terms of eulogy or of dispraise. There is a spiritual impotentiality, so to say, which cannot be trusted away from conventional incentives and supports. Every mite which it drops into the treasury of the Lord must be inscribed with the name of some individual or sect and heralded to the world. Not so the missionary of Islam in Africa who, strong in his belief in the doctrines he promulgates, acts everywhere on his own initiative; his only support being the words of the Koran, Ajri ind Allahi, "My reward is with God." No human praise elates and no human censure depresses him. "Why don't you send reports of your successes to the local 
papers?" I asked one of the active Muslim missionaries at Lagos. "We report to God," was the laconic but significant reply, and he added, with a cynical air, a sentiment something like that expressed in the lines of Metastasio:

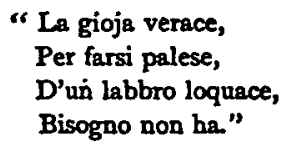

I must confess that whenever I have seen these men at workand I have frequently seen them-and have contrasted their zealous efforts, their self-sacrifice, their indifference to human recognition and applause, with the timidity, the hesitancy, the helpless dependence upon foreign aid and stimulus of native missionaries of Christianity, something of the feeling has come over me which Renan says was excited in him every time he witnessed the daily prayers of Muslims, "Je ne suis jamais entre dans une mosquee sans une vive emotion, le dirai-je? sans un certain regret de n'être pas musulman." 1

Islam in Soudan is protective in its influence and permanent in its conquests. When the Muslim missionary has once brought a community within the pale of Islam, it is for ever sheltered from the blighting influence of foreign trade and commerce. This the religion from Europe has nowhere done and cannot do.

All the representatives of His Majesty at present administering the affairs of the West African Colonies agree in their testimony as to the preservative and uplifting influence of Islam.

Sir Frederick Lugard in his report pays to Muslim influence the following compliment: "It has appeared to me that it would be advisable to include in Northern Nigeria any large towns close to the frontier which might become depots for the storage and sale of liquor." 2

The inhabitants of Northern Nigeria are mostly Mohammedans and they have compelled the Government to legislate against

\footnotetext{
1 Emest Renan, L'Islamisme et la Science, p. 19, quoted by Amold, Preaching of Islam, p. 339.

- See Report of Sir Frederick Lugard, High Commissioner, on Northern Nigeria, published in West Africa, March 8, 1902 ; also Despatch of Sir George Denton, Governor of Gambia, published in West Africa, August 2, 1902. Also Message or Sir William MacGregor, delivered to the Legislative Council of Lagos in 1902
} 
the introduction of liquor by the practical argument of refusing to purchase it.

His Excellency Sir George Denton, Governor of the Gambia, in an official letter to the Colonial Office describing his last visit (January 1902) to the Hinterland says :

"One thing that I noticed on this visit, was the progress which Mohammedanism is making in this part of the world. But a very little time ago the Soninkes were very numerous, as also were the Pagan Fulahs; now every day the Marabouts are increasing, and before long they will number three-quarters at least of the population. This, I think, will on the whole be of decided advantage to the Colony, though the revenue from the spirit trade, never a large amount on the Gambia, wall fall off no doubt, but it will, I believe, be possible to make up the sum lost from other sources."

On the other hand, Sir Matthew Nathan, Governor of the Gold Coast Colony, complains in an official letter dated January 18 , 1902, of the drunken and slovenly habits of some of his chiefs who have not yet come under Islamic influence. ${ }^{1}$ The $M$ issionary Herald (Boston, U.S., August I902) says :

"It is not many years since the Christian chief Khama removed his residence to Phalapye, for the sufficient reason that he wished his people to be out of the way of the temptations to drink which surrounded them at their old capital. He is to remove again, but for what reason we are not as yet informed. His new station is to be Serone, about forty miles north-west of Phalapye."

It is needless to add that if Khama and his people had been converted to Islam there would have been no necessity for breaking up his home. On the contrary, the Government would have been compelled, as in Northern Nigeria, to prohibit drink.

At the Ecumenical Conference in New York to which reference has been made above, numerous and earnest complaints were made by missionaries of the demoralization brought among their converts by civilization. Rev. John G. Paton, D.D., New Hebrides, Presbyterian missionary, said: "After we give the Gospel to the heathen, and life and property are safe, trade

1 The Gold Coast Aborigines, April 19, 1902. 
follows us, not to uphold the work of God, but to give the natives rum and brandy, which ruin both their bodies and souls." 1

Dr. Theodore L. Cuyler, another veteran evangelist, said, speaking of the Philippine Islands :

"They are under our flag. That means authority, opportunity, responsibility. Under our flag! It is a most terrible truth that that flag, our "Old Glory," as we call it, floats to-night over American drinking dens and American slaughter houses of body and soul in Manila. (Cries of 'Shame!'). Yes, shame! shame! $\mathrm{Oh}$, if it must hang above those drinking hells, then, for Heaven's sake, hang it at half mast."

Every one will remember the fervent appeals of the Bishop of Western Equatorial Africa against the liquor traffic. It is clear to all acquainted with the conditions that, unless Christian missionaries can induce the nations whose citizens they are to suppress the export of liquor to Africa, their labours on this continent will be those of the Danaides, and Islam, keeping immeasurably in advance in its influence, will finally absorb the whole of the intellectual and physical strength of the country.

With Islam Africa is safe at least from physical destruction: with popular Christianity it might share the fate of the North American Indians, Sandwich Islanders, New Zealanders, \&c. The Philippines cannot be in the danger of those countries, because Islam has a strong hold upon large portions of the population; the rest are under the conservative influence of the Roman Catholics, under whom, wherever they go, native races are preserved. One of the reasons for this favourable result is given in a recent speech delivered in London by Bishop Hoare of Victoria, that the Roman Catholic missionaries do not evangelize, but occupy themselves with educational work." 8

Islam in Africa is again and again reproached with backwardness. With contemptuous reference to its so-called "stagnant" condition, the lines of Lord Houghton are flung into its face.

"So while the world rolls on from change to change, And realms of thought expand,

The Letter stands without expanse or range, Stiff as a dead man's hand." a

1 Ecuntenical Missionary Conference, vol i p. 383.

2 Church Missionary Intelligencer, August, 1902.

- Poetical Works, vol. i. p. 164

3) Vol. 2 
In the case of Africa, we must say " better a cycle of Cathay than fifty years of Europe." Better this "stiffness" than the pliability which has permitted dark races in contact with civilization to "roll on from change to change," till they "rolled" out of existence. This "stiffness" has proved a powerful antiseptic. But the poet adds-

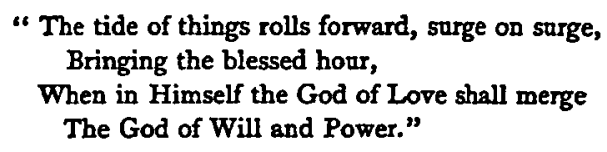

Then will be Africa's time. Meanwhile, she loiters asleep during the march of material progress and political rule.

The charge is frequently brought against Islam in Soudan that it always brings with it fierce bostility to Europeans and Christians. This charge, according to the testimony of competent witnesses, cannot be sustained so far as Negro Muslims are concerned, who are everywhere peaceable, tolerant, and non-political in their aspirations. Captain Binger, who spent several years in Soudan, and has held official appointments under the French Government among Soudanese says, speaking of the Mohammedans of Kong :-

"Ils sont bons musulmans mais tolerants, et il n'ont rien du fanatisme des musulmans foulbé du Maçina ou des Toucouleurs.

Tous les musulmans sont très tolérants; aucun d'eux n'est assez sot pour ne pas preter une marmite ou une calebasse $d$ un infidèle, comme cela a lieu dans quelques contrées habitées par des Foulbés musulmans .... Ils m'ont souvent interrogé sur les différences qu'offrent ces trois religions (qu'ils nomment Mouça Sila, Insa Sila, Mohammadou Sila) entre elles, mais aucun d'eux n'a été assez sot pour me dire que la religion musulmane est la meilleure, je dois le dire d leur louange. ${ }^{1}$

M. Felix Dubois, another traveller in Islamic Soudan, whose knowledge of Arabic gave him exceptional advantages for learning the people, says:

"The character of the Soudanese in general is essentially based upon a foundation of goodness and docility, and they lack the elements necessary to produce the savage sectarian so

1 Du Niger au Golfe de Guinke, par le pays de Kong at le Mossi, par le Capitaine Binger, 1887-1889. Paris, 1892. 
common to the north of Africa and Asia . . . Contemporary history of the Soudan has, however, revealed frequent fanatical explosions and numerous holy wars. The curious biography of El Moucherli has disclosed one of the causes of these disturbances, namely, the influence of the Arabian Musulman, which at the present moment principally makes itself felt by the propaganda of the sect of the Senoussi . . . It is, therefore, through direct or indirect contact with the foreign Musulman of the white races that the Soudanese is transformed into a sectarian, and it is from this contact that we must preserve him in order to maintain peace in the Nigerian countries.

"Finally, and most characteristically, it is not the pure-bred Negro among the population of the Soudan who allows himself to be led into holy wars, but it is those people in whose veins the blood of the white races flows, the Foulbes of Berber origin, and the Toucouleurs, who are a mixture of the Foulbe and the Negro of Mali." 1

Mr. E. D. Morel, in an exceedingly interesting paper published in the Journal of the African Society (January, I902), makes the reassuring statement that France "has broken the power of the cross-races, upon whom she is conferring the means of existence without rapine, murder, and slave-raiding, and has made practically impossible the renewal of jihads by the Tijaniyah Sect on anything like a large scale." 2

The Soudanese Muslims are the most loyal of all the natives under European rule. In religious matters they listen for fetwas from Constantinople, not Mecca. They take no part in the dispute about the Khalifate. All roads lead to Rome in the religious ideas of Europe, so in the religious ideas of Soudanese

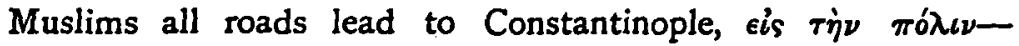
Istamboul.

Al Hagg Omar, who waged extensive wars in Soudan in the name of Islam, was a Toucouleur. Samudu or Samory, a fullblooded negro, was an uninstructed fanatic attempting, with a misguided zeal, to spread Islam among Pagan tribes by means of the sword. But in all his conquests he never aspired to ultimate supremacy for himself. At the time of his greatest

1 Timbuctoo the Mysterious, pp. 300, 301.

Toumal of the African Society, Jan. 1902. 
successes, when he was the unquestioned potentate of the whole of the valley west of the Niger, he desired, by a proper instinct, to surrender his country to British rule, and as an earnest of this gave large concessions to the British capitalist, and this not from any cowardly or servile spirit, but because he recognized the destiny and limitations of his race. The pure Soudanese as pointed out by Dubois, do not aspire to, and they know themselves to be incapable of, extensive secular sway. In the colony of Senegal and its hinterland, where there are hundreds of thousands of them, they have no political associations, and no journalism. At St. Louis, where there is every facility for such a thing, they have not a single newspaper, and they are happier for it than their brethren in other parts of West Africa, who rejoice in the advantages and "freedom of the Press."

Another charge brought against Muslims, especially those of Soudan, is that their conception of woman and her place is degrading to her and to humanity. But this charge is brought only by those unacquainted with the facts-untravelled and half-educated people.

I have neither time nor inclination to discuss the question here, so far as Africa is concerned, and to give the results of my own experience. Miss Kingsley has shown that honourable homage was paid to women in Africa, both Mohammedan and Pagan, long before Europe understood or appreciated the question. At the recent celebration of their Majesties' Coronation in this colony, two ladies from the hinterland were received by the Government as Queens in their own right.

With regard to the future of Islam it seems to be a cherished idea with certain European writers that the increasing political subordination of Islam means its disappearance as a religious power. Mr. Bryce in his lecture above referred to, looking at general political conditions, exclaims, "Conceive the difference if Islam were within two centuries to disappear from the earth. The thing is not impossible; perhaps not even improbable." But the symbol of Islam is the crescent not the waning moon. Its political disintegration intensifies its religious force. A writer in La Depeche Coloniale, January 27, 1902, calls attention to this important fact: 
"Par une coincidence inexplicable en apparence mais absolument logique et fatale en réalité, les Etats musulmans partout sont en voie de decadence, d'affaiblissement, de ruine, alors que la religion de l'Islam fait de nombreuses recrues dans les populations africaines et asiatiques. ... .

"Déja la Russie a mis la main sur les sultanats de l'Asie occidentale; l'Egypte, la Tunisie ne sont plus que des protectorats. L'Afghanistan, la Perse, la Turquie, le Maroc ne vivent plus qu'à l'état précaire, grâce au rivalités des puissances européennes qui convoitent leur héritage. Et cependant, l'Islam non seulement subsiste, mais s'etend, fait des prosélytes, gagne des fidèles." Sic volvere Parcae.

There is no earthly prospect of the disappearance of Islam from the religious forces of the world. It will continue as long as Roman Catholicism will, as long as cloud-capped towers, gorgeous palaces, and solemn temples remain. Learned African Muslims declare that Asia and Africa are the fated possessions of Ishmael, while Europe and America have been given to Isaac-Abraham's two sons. The Cross, while surrendering to the Crescent the localities which it first consecrated, has opened for itself new fields in the West.

EDWARd W. BLYDEN.

Sirrra Lronr, September I3, 1902.

NoTn-The writer of the above is a pure blooded native, and in a letter to the African Society says, "I think it is only fair to Africa to let one of her sons explain what millions of his people really feel and think, whether it conform to or is antagonistic to European sentiment." $-[E D$. 